\title{
THE ORGANISATION OF PLANT BREEDING AND GENETICS IN SWEDEN
}

\author{
D. LEWIS \\ John Innes Horticultural Institution, Merton
}

Received 24.vii.47

SixTy years ago the first plant breeding station in Sweden was founded at the village of Svalöf in the southernmost district of Skåne ; to-day there are several important institutes, each with branch stations and sub-stations distributed over the country. Most of these institutes and stations are State supported, others are owned by private seed companies, some of which receive State aid for research. Plant breeding has therefore been taken seriously both by the State and by private enterprise. Its justification is to be found in the increased yields of crops over the last fifty years; in wheat, a 30 per cent. increase has been estimated to be due to improved varieties alone. This fact, together with the comparatively small size but diverse nature of the country, makes the organisation one very suitable for study.

Plant breeding and genetics that is controlled by the State is designed to meet three main requirements. (I) Research into new methods of breeding and fundamental knowledge. (2) Breeding improved varieties suited to many different conditions of soil and climate. (3) The efficient maintenance and distribution of the new varieties after they have been placed on the market.

Fundamental research is carried out at the Institute of Genetics, University of Lund, under Prof. Müntzing, and at the Plant Breeding Institute at Svalöf under Prof. Åkerman. The Institute of Genetics is also responsible for genetic teaching. These two Institutes have always been in very close touch, and in fact they were at first under one Director, Prof, Nilsson-Ehle. Even now the experimental grounds for the Genetic Institute are provided by the Plant Breeding Institute ; this dependence has its disadvantages which, however, will soon be removed by a decision to provide a new building with modern equipment in its own experimental grounds at Lund. This, and the proposed doubling of the staff are evidence of the importance attached to the fundamental and teaching aspects.

Genetical teaching and research has also been carried out at the Agricultural College established at Ultuna near Uppsala under the direction of Prof. Turesson. This institute is also to be enlarged.

The work, which has already been remarkably successful, is chiefly devoted to the production of new crops by acclimatisation, hybridisation and the doubling of chromosome numbers. 
Although the main function of the Plant Breeding Institute at Svalöf is the breeding of new varieties of agricultural crops, fundamental work and the search for possible new methods of breeding are encouraged. Of this type of work the X-ray changes induced in barley by Dr Gustafsson have already given results of importance to practical plant breeding; while the work of Dr Levan on the effects of colchicine and other polyploid-producing agents on the nucleus have given polyploids which show promising practical results.

The second objective, the breeding of improved varieties suitable for environments, is done at the main institute at Svalöf in conjunction with the branch stations, which are distributed over the country according to the map, fig. I. The co-operation of the main institute with the branch stations is a very important factor in the efficient use of the breeding material.

Breeding and initial selection are done mainly at Svalöf, while in later generations testing and selection are done both at the main station and at the branch stations. In this way, under the varied conditions of the branch stations, the full potentialities of the crosses can be exploited so that varieties which may be suitable for particular local conditions would not be lost. For plants which are confined to a light soil, it has been found that even the initial breeding work must be done on such soil, and for this purpose the out-station at Ugerup is used.

In the course of the breeding work it has been found that, with some plants such as wheat, oats and timothy grass, a single variety can be produced which is very suitable over large areas of cultivation. Such versatile varieties, however, have not been found in many other crops, and, with these, it has been necessary to produce several varieties to suit local conditions. The drawback with such material is that the multiplicity of varieties entails an increase in the cost of maintaining the élite and stock seeds.

Recently, the policy of doing the breeding work at the main station has been modified. With a highly specialised crop that has to fulfil the requirements of a complex industrial process it may be necessary to set up a breeding station to deal only with this crop. Flax, for which there has recently been a great demand owing to the shortage of imported textiles, is bred separately from other crops at Månsabo near Svalöf under the directorship of Dr Grenhall.

The third requirement, the maintenance and distribution of varieties produced at the Institute, is a difficult problem, as in other countries. It has been solved, at least for seed crops in Sweden, in this way. The main breeding Institute at Svalöf and the branch stations are owned by the Swedish Seed Association, which was formed in I 892-actual breeding having begun in I886-to encourage the use of improved varieties of agricultural crops. This common control of the main and branch stations ensures their full co-operation. The association, however, does not distribute the new varieties; this is 
done by a private company, the General Swedish Seed Company, formed specially for the purpose. It is run on orthodox business lines but has certain obligations to the Association. The Company has the sole right to all new varieties bred by the Association, for which a fixed royalty and a percentage of the sales are paid to the breeding Association; and the Company agrees to the control of its business partly by the Central Government Seed Testing Station. The seed company keeps and distributes the stock seed but the Breeding Institute produces and controls the élite seed. Finally, the Company has no control over the work of the Breeding Institute.

This system seems to work very satisfactorily in Sweden, and furthermore, it is acceptable to most of the rival seed firms because, as will be shown later, these private firms have their own departments of genetical research. It could not be expected to work smoothly in a country where seed firms do not have their own trained plant breeders. Under such conditions the system adopted in Denmark is probably the best. Here all the seed firms contribute to a society which carries out the breeding work and maintains the purity of the élite seed; each seed firm benefits by growing and distributing the bulk seed of any new product of research. Thus with this method the seed grower and the breeder are organised to their mutual benefit.

Both methods, the Swedish and the Danish, reduce the unnecessary replication of varieties of similar merit and type to a minimum, and they also discourage the pernicious practice of renaming an already existing variety to give the impression that it is something new. This is obviously true of the Danish co-operative system, and it also applies to the Swedish system, because the new products of both the State Breeding Institutes and the private seed firms are rigorously tested at Government stations before they are marketed.

With breeding that is carried out by private seed companies the problem of seed distribution does not arise. In Sweden one of the largest of such breeding stations is at Weibullsholm near Landskrona on the southern point of the West Coast. This is owned by the firm of W. Weibull \& Co., which originated in 1870 as a small seed farm. The Company has developed enormously, and in 1907 the first geneticist was appointed to direct the breeding work. At the present time the breeding station of this firm is under Dr Lamprecht and is organised into five departments, each dealing with different crops, including all cereals, fodder plants, vegetables and flowers. Many valuable varieties of plants have originated from this station, and at present the varieties of wheat produced there are among the best in Sweden. Apart from the trials made at Weibullsholm, all new varieties are finally tested for yield at the Government testing station.

Close by, at Hilleshög, is another large private breeding station owned by the Swedish Sugar Manufacturing Company and directed by $\mathrm{Dr}$ Rasmusson. Its work is confined to sugar-beet; the strains 
of beet that have been produced there are extremely successful in competition with other strains both in Sweden and in other countries.

The work of selection and isolation is carried out at a number of branch stations. One important result of selecting in different environments has been found in sugar-beet. Starting with somewhat heterozygous material, selection for such polygenic characters as high sugar content and low noxious nitrogen is made on plants grown at a number of different places. The basis of selection is the same in all the localities, and the end performance of the lines is similar. Genetically, however, the end-result is quite different. This is shown by the heterosis in the $F_{1}$, which is found when these selected lines from different localities are crossed. Thus, in an outbreeding plant like sugar-beet, selecting a reduced number of phenotypes in one environment leads to greater homozygosity of the particular polygenic complexes selected. The same basis of selection in a different environment also leads to more homozygosity but of different complexes. Intercrossing the two selections would lead to heterosis. The practical importance of such a method is self-evident, and steps are being taken to exploit this commercially.

Triploid and tetraploid sugar-beet have given promising results both at Hilleshög and Svalöf.

Other private firms engaged in breeding are those of $\mathrm{O}$. J. Olson at Hammenhög and Algot Holmberg \& Sons at Norrköping; these are notable for root and herbage plants and for their vegetable and flower seeds. Although the breeding of vegetables is carried out by a number of private firms, the State also provides for breeding in these crops at a department of the Horticultural Research Station at Melangård, Alnarp, under Dr Lamm.

The success of these privately-owned breeding stations is probably due to two main factors: ( 1 ) A trained staff under a scientist is employed, (2) the companies are large and can afford the capital outlay and continued expense necessary for breeding work on an adequate scale. Wiebullsholm is owned by a large single company, while Hilleshög station is owned by a combine of all sugar manufacturers in Sweden.

To turn to a different class of plants, breeding has recently been started in forest and fruit trees. Early in 1936 the Association of Forest Tree Breeding was founded under the directorship of Prof. Sylvén; later in the same year the Association was supported by the Forest Owners' Society and, in 1937, by the Swedish Match Company. In $193^{8}$ the sum of 400,500 crowns was given by the Knut and Alice Wallenberg Foundation to purchase the grounds and equipment for the Forest Tree Breeding Station at Ekebo near Svalöf. Four branch stations have since been added.

The Association started the work by making an inventory of Swedish forests and by laying down, under varied conditions, trials of material collected from the whole country. In the breeding work 
that followed, all the techniques of modern genetics have been applied; these include hybrid seed production, statistical design of trials, artificial illumination for winter flowering and colchicine treatment. Special methods, which are necessary for the ease of handling, have been devised ; one of these is the grafting of flowering shoots on to small stock trees, thus making a small flowering tree.

Already it is possible to generalise from the work; for example, in conifers, hybrid vigour between diploid strains shows good results while polyploidy is of doubtful value; in deciduous trees on the other hand, a marked improvement can be effected with polyploidy. Thus triploid forms of ash and poplar, found among wild populations, have a growth rate nearly twice that of the diploid; triploids obtained in oak from twin acorns have a similar advantage. Perhaps of equal importance is the discovery of a general correlation between the growth and performance of young seedlings and the value of the mature trees, thus giving a basis for selection in the young seedlings.

In 1938, when the State Horticultural Research Stations were set up at Alnarp and Balsgård under Prof. Nillson, fruit breeding was put on a national basis. Before this, however, Prof. Dahl and Dr Johansson had been breeding fruit at the Horticultural College at Alnarp. Improvement of soft and tree fruits is in progress, and already a result has been obtained which may be a starting-point of a whole series of new apple varieties. This is the production of tetraploid apples by Prof. Ehle's method of raising many seedlings from the already existing triploid varieties. A small percentage of the progeny are tetraploids, of which some have fruited with promising results.

Before new varieties of fruit are put on the market they are tested at two State branch stations at Rånna, east of Gothenburg and at Nychelby near Stockholm, and also at schools and privately-owned fruit farms. The schools and growers record crop weights, season of ripening, incidence of disease and other characters of economic value; in return for this the trees are supplied free and, apart from small samples of fruit, the crop belongs to the grower. This system works well, particularly with the schools, mainly because their agricultural teaching is suited to this kind of work.

Proved varieties are propagated and sold by a State Horticultural College, which has a commercial fruit department; this method is similar to the distribution of agricultural seed produced by the Svalof station and it avoids the difficulty of favouring any one commercial firm.

An encouraging sign to the tree breeder is the speed with which new polyploid and hybrid forest and fruit trees have been propagated. The enterprising nursery firm of Holgar Jensen of Ramlösa already grows several new forest trees; this firm also does useful breeding work with Rubus and Fragaria.

Again, as in the agricultural crops, the fruit breeding is supported mainly by the State and, to a less extent, by private subscription, 
but the whole work gains much by the genuine interest taken in it throughout the country. The fact that the early breeding in cereals

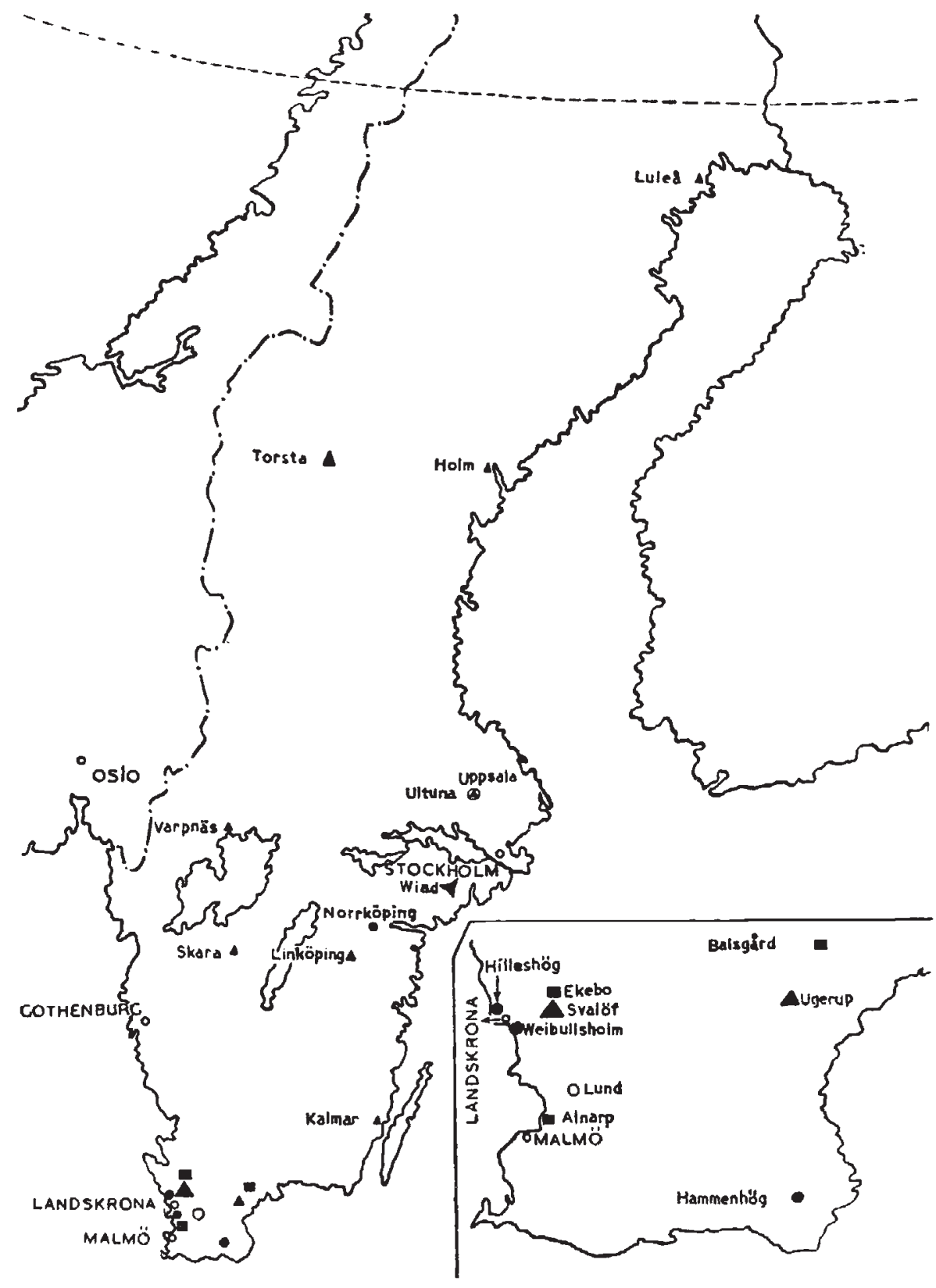

paid handsomely has naturally been a great incentive to extend such work to long-term forest and fruit crops. 